\title{
Calcium induces salinity tolerance in pistachio rootstocks
}

\author{
Vahid Tavallalı*, Majid RaHEMI, Bahman PaNAHI
}

Horticultural Science Department, Agric. Fac., Univ. Shiraz, Shiraz, Iran tavallali@shirazu.ac.ir

\section{${ }^{*}$ Correspondence and reprints}

Received 7 January 2008 Accepted 21 April 2008

Fruits, 2008, vol. 63, p. 285-296 (c) 2008 Cirad/EDP Sciences All rights reserved DOI: $10.1051 /$ fruits:2008024 www.fruits-journal.org RESUMEN ESPAÑOL, p. 296

\section{Calcium induces salinity tolerance in pistachio rootstocks.}

Abstract - Introduction. Saline soils may exert a different effect on seed germination and seedling growth. Materials and methods. The seeds of two rootstocks of pistachio (Pistacia vera), Ghazvini and Badami-e-zarand, were incubated at $20^{\circ} \mathrm{C}$ in the dark in a $150 \mathrm{mM} \mathrm{NaCl}$ solution or in $150 \mathrm{mM} \mathrm{NaCl}$ solutions amended with $(50,100$ and 150$) \mathrm{mM} \mathrm{CaSO}_{4}$. Seeds were planted in pots containing a mixture of garden soil, sand and compost $(1 / 3 \mathrm{v} / \mathrm{v})$ to investigate the effect of calcium sulphate on plants grown under salt stress. Irrigation water treatments were control (deionised water alone); salinity stress ( $150 \mathrm{mM} \mathrm{NaCl}$ ); salinity with $50 \mathrm{mM} \mathrm{CaSO}_{4}$; salinity with $100 \mathrm{mM} \mathrm{CaSO}_{4}$; and salinity with $150 \mathrm{mM} \mathrm{CaSO}$. Results and discussion. In all treatments, both the final germination percentage and the final percentage of seeds with emerging seedlings longer than $20 \mathrm{~mm}$ were higher in the Ghazvini rootstock than in the Badami-e-zarand rootstock. Both the final germination percentage and the final percentage of seeds with emerging seedlings were significantly increased with increasing $\mathrm{CaSO}_{4}$ concentration, except at the highest $\mathrm{CaSO}_{4}$ concentration. The plants grown under $150 \mathrm{mM} \mathrm{NaCl}$ produced less dry matter and had lower chlorophyll content than those grown without $\mathrm{NaCl}$. Supplementary $\mathrm{CaSO}_{4}$ only at (50 and 100) $\mathrm{mM}$ concentrations ameliorated the negative effects of salinity on plant dry matter and chlorophyll content. Sodium (Na) concentration in plant tissues increased in both leaves and roots of plants under the $\mathrm{NaCl}$ treatment alone. The Ghazvini rootstock had much lower $\mathrm{Na}$. Additions of $\mathrm{CaSO}_{4}$ significantly lowered the concentration of $\mathrm{Na}$ in both leaves and roots. The Ghazvini rootstock was more tolerant to salinity than the Badami-e-zarand rootstock. The accumulation of $\mathrm{Na}$ in leaves and roots indicates a possible mechanism whereby cv. Ghazvini copes with salinity in the rooting medium, and/or may indicate the existence of an inhibition mechanism of Na transport to leaves. Concentrations of $\mathrm{Ca}$ and $\mathrm{K}$ were lower in the plants grown at high $\mathrm{NaCl}$ concentration than in those under the control treatment, and, for the cv. Ghazvini, these two element's concentrations were increased in both leaves and roots for the plants with calcium sulphate treatment; for the cv. Badamie-zarand, these concentrations were increased in only the roots.

Iran Islamic Republic / Pistacia vera / germination / growth / osmotic stress / saline water / calcium sulphate / salt tolerance

Le calcium induit une tolérance au sel dans les porte-greffes de pistachiers. Résumé - Introduction. Les sols salins peuvent exercer différents effets sur la germination des graines et sur la croissance des jeunes plantes. Matériel et méthodes. Les graines de deux porte-greffes de pistachiers (cultivars Ghazvini et Badami-e-zarand de Pistacia vera) ont été incubées à $20^{\circ} \mathrm{C}$ à l'obscurité dans une solution à $150 \mathrm{mM}$ de $\mathrm{NaCl}$ ou dans des solutions de $150 \mathrm{mM}$ de $\mathrm{NaCl}$ enrichies avec $(50,100$, et 150) $\mathrm{mM}_{\text {de }} \mathrm{CaSO}_{4}$. Ces graines ont été plantées dans des pots contenant un mélange de sol de jardin, sable et compost $(1 / 3 \mathrm{v} / \mathrm{v})$ pour étudier l'effet du sulfate de calcium sur des plantes cultivées en condition de stress salin. Les traitements appliqués par l'eau d'irrigation ont consisté en un traitement témoin (eau désionisée seule); un traitement de stress salin $(150 \mathrm{mM} \mathrm{de} \mathrm{NaCl})$; trois traitements de stress salin avec $50 \mathrm{mM}$ de CaSO4, $100 \mathrm{mM}$ de CaSO4, et $150 \mathrm{mM}$ de CaSO4 ajoutés respectivement à la solution saline $(150 \mathrm{mM}$ de NaCl) . Résultats et discussion. Pour tous les traitements, le pourcentage final de germination et le pourcentage final des graines ayant donné des plantules de plus de $20 \mathrm{~mm}$ ont été les plus élevés pour le porte-greffe Ghazvini que pour le porte-greffe Badami-e-zarand. Le pourcentage final de germination et le pourcentage final des graines avec plantules ont été sensiblement augmentés avec l'accroissement de la concentration en $\mathrm{CaSO}_{4}$, excepté à la concentration la plus élevée en $\mathrm{CaSO}_{4}$. Les plantes cultivées avec $150 \mathrm{mM}$ de $\mathrm{NaCl}$ ont élaboré moins de matière sèche et ont eu une teneur inférieure en chlorophylle par rapport à celles développées sans $\mathrm{NaCl}$. Seuls des ajouts de $\mathrm{CaSO}_{4}$ aux concentrations de (50 et 100) $\mathrm{mM}$ ont permis de pallier les effets négatifs de la salinité sur le contenu en matière sèche et en chlorophylle de plante. La concentration en sodium $(\mathrm{Na})$ dans les tissus végétaux a augmenté à la fois dans les feuilles et dans les racines des plantes dans le seul traitement avec NaCl. Le porte-greffe Ghazvini a eu une teneur en $\mathrm{Na}$ très inférieure. L'addition de $\mathrm{CaSO}_{4}$ à la solution saline a abaissé de manière significative la concentration de Na dans les feuilles et racines. Le porte-greffe Ghazvini a été plus tolérant à la salinité que le porte-greffe Badami-e-zarand. L'accumulation de Na dans les feuilles et les racines indique un mécanisme possible par lequel le cv. Ghazvini ferait face à la salinité dans le milieu d'enracinement, et/ou pourrait indiquer l'existence d'un mécanisme d'inhibition du transport de Na vers les feuilles. Les concentrations de Ca et de K ont été inférieures dans les plantes cultivées en présence de NaCl par rapport à celles des plantes témoins, et, pour le cv. Ghazvini, les teneurs en ces deux éléments ont été augmentées dans les feuilles et les racines pour les plantes traitées avec du sulfate de calcium ; pour le cv. Badamie-zarand, les teneurs ont été augmentées dans les seules racines.

Iran République islamique / Pistacia vera / germination / croissance / stress osmotique / eau saline / sulfate de calcium / tolérance au sel 


\section{Introduction}

The relationship between salinity and mineral nutrition of horticultural crops is extremely complex, and a complete understanding of the intricate interactions involved would require input from a multidisciplinary team of scientists [20]. Most horticultural crops are glycophytes and can grow only under lowsalinity conditions [2]. The mechanisms they have developed for absorbing, transporting and utilising mineral nutrients from nonsaline substrates may not operate as efficiently or as effectively under saline as non-saline conditions [1]. The interactions affect-ing nutrient availability, uptake and distribution are topics that are highly complex in the absence of salinity or other stresses [3].

Saline soils contain various compositions of soluble salts, each of which has a different effect on the initial growth of plants [4], and the compositions of soluble salts in saline soils can differ greatly among locations [5]. Salinity can be minimised with reclamation, and drainage technology, but the cost of engineering and management is very high. Increasing costs for water and energy emphasise the need for an alternative strategy [6]. Among salt components, $\mathrm{Ca}^{2+}$ is noteworthy because it significantly affects the salinity responses of plants in both initial growth $[5,7]$ and later developmental stages [8].

One important effect of salts on the initial growth of plants is toxicity. At least some of the effects of salt toxicity originate from the displacement of $\mathrm{Ca}^{2+}$ bound to the external surface of the plasma membrane by more toxic metal cations, and the subsequent impairment of membrane integrity and permeability. Calcium in the external medium alleviates this type of salt toxicity by re-displacing the cations on the membrane with $\mathrm{Ca}^{2+}[9]$. Sodium toxicity and its alleviation by $\mathrm{Ca}^{2+}$ have been studied extensively $[9,10]$.

$\mathrm{NaCl}$ affects the permeability of the plasma membrane and increases influx of external ions and efflux of cytosolic solutes $[10,11]$ in plant cells. Secondly, $\mathrm{NaCl}$ causes hardening of the cell wall [12] and a decrease in water conductance of the plasma mem- brane $[13,14]$. These effects of $\mathrm{NaCl}$ on cellular functions are alleviated by the addition of $\mathrm{Ca}^{2+}$ to the external medium $[9,11,13]$. These effects of salts on the functions of the cell membranes and the cell walls may affect the water potential of the cytosol and cellular extensibility and, thus, may affect seed germination and seedling growth. Therefore, it has been hypothesised that high concentrations of Ca can protect the cell membrane from the adverse effects of salinity [15]. Externally-supplied Ca has been shown to ameliorate the adverse effect of salinity in plants, presumably by facilitating higher [K:Na] ratios [16].

In Iran, approximately $12.5 \%$ of agricultural land is affected by increased or natural salinity [17]. In that country, pistachio (Pistacia vera $\mathrm{L}$.) has been grown commercially for many years and, currently, pistachio plantations encompass about 390000 ha with annual production of around $150000 \mathrm{t}$ of pistachio nuts. Most pistachio plantations are on sodic soils and irrigated with low quality, saline water. Poor quality of irrigation water in association with sodic soils has reduced yields of pistachio over recent years, especially in the southeast of Iran in Kerman, and in central Iran, particularly in the Yazd and Qhom regions. Despite reduced yields with increasing salinity, pistachio has been described as salt-tolerant [18-20] and is potentially an alternative to salt-sensitive pecan (Carya illinoinensis) or almond (Prunus amygdalus). However, symptoms of toxicity in pistachio and cultivar differences in susceptibility to salinity have been previously described [18-20]. For example, saline stress can cause decreased growth, alters photosynthetic rates and causes morphological changes in the leaves $[18,19]$.

In some countries, such as Iran, Pistacia vera $\mathrm{L}$. is used as a rootstock. Rootstock choice has been shown to influence nutrient uptake efficiency; likewise, the salt tolerance of different rootstocks has been investigated. Therefore, an alternative approach could be to add Ca to a growth medium that is known to be or may become saline at some time during the crop growth cycle.

We conducted an experiment with seeds and seedlings of two rootstocks of pistachio 
to assess the effectiveness of supplemental $\mathrm{Ca}$ in overcoming salinity stress. Our aim was to determine if this approach would correct $\mathrm{Ca}$ and $\mathrm{K}$ deficiencies in seedlings in the presence of high $\mathrm{NaCl}$ and to assess the effects of supplemental $\mathrm{Ca}$ on seed germination. Physiological parameters (e.g., dry weight, relative water content and membrane permeability) of these rootstocks were compared because one of them, Ghazvini, is considered to be the most salt-tolerant and the other, Badami-e-zarand, is known for sensitivity to salinity. A special objective of this work was to determine the possible mechanism developed by salt-tolerant pistachio rootstocks.

\section{Materials and methods}

Seeds of two pistachio (Pistacia vera $\mathrm{L}$.) rootstocks, Ghazvini and Badami-e-zarand, were collected from plants growing in field plots at the Pistachio Research Institute in Rafsanjan (Iran). These seeds were pre-treated for $24 \mathrm{~h}$ with $0.01 \%$ Captan solution. Replicates of 40 seeds were sown on three layers of filter paper (Toyo, No. 1) in 120$\mathrm{mm}$ plastic petri dishes. About $15 \mathrm{~mL}$ of deionised water or a salt solution was added to each petri dish, so that about half the volume of each seed was immersed. The water potential, $\Psi_{\mathrm{W}}$, of saline was calculated from van't Hoff's law, assuming that salt in solution was dissociated into ions. As the calcium sulphate will not be fully dissociated, the water potentials of the calcium sulphate solutions were measured, not calculated from the van't Hoff relationship $\left(\Psi_{\mathrm{W}}\right.$ of $\mathrm{CaSO}_{4}$ solutions: $50 \mathrm{mM}=-0.08 \mathrm{MPa}$, $100 \mathrm{mM}=-0.2 \mathrm{MPa}, 150 \mathrm{mM}=-0.35 \mathrm{MPa}$ ). In addition to the water potential, $\Psi_{\mathrm{W}}$, salt concentration in solutions was expressed on a molal basis (mMolal; $\mathrm{mM} \cdot \mathrm{kg}^{-1}$ of water) The petri dishes were covered with lids, and the seeds were incubated at $20^{\circ} \mathrm{C}$ in the dark, because the seeds germinate favourably under these conditions. About twothirds of the volume of the solution in each petri dish was replaced daily with fresh treatment solution, to avoid changes in solute concentration.

\subsection{Effects of salt solution with different $\mathrm{CaSO}_{4}$ concentrations on seed germination and seedling growth}

Seeds were incubated in a salt $\mathrm{NaCl}$ solution $\left(\Psi_{\mathrm{W}}=-0.7, \mathrm{MPa}=150 \mathrm{mM}\right)$ with different $\mathrm{CaSO}_{4}$ concentrations $[(0,50,100$ and 150) $\mathrm{mM}$. The seeds were observed daily for $20 \mathrm{~d}$ in dim light through a scale; the numbers of both germinated seeds (seeds with emerging seedlings longer than $3 \mathrm{~mm}$ ) and seeds with emerging seedlings longer than $20 \mathrm{~mm}$ were counted. After $20 \mathrm{~d}$ of incubation, the final germination percentage $\left(\mathrm{G}_{\mathrm{F} \%}\right)$ and the final percentage of seeds with emerging seedlings longer than $20 \mathrm{~mm}$ $\left(\mathrm{S}_{\mathrm{F} \%}\right)$ were determined. The control was incubated in deionised water. Each treatment was replicated four times.

\subsection{Evaluation of salinity $+\mathrm{CaSO}_{4}$ on seedlings}

After germination of seeds, 40 seedlings (20 seedlings of each rootstock) were grown in plastic pots filled with a silty-loam texture soil (a mixture of garden soil, sand and compost $1 / 3 \mathrm{v} / \mathrm{v}$ ) with $\mathrm{pH} 7.3$, electrical conductivity $\mathrm{EC}=2 \mathrm{dS} \cdot \mathrm{m}^{-1}, 0.8 \%$ organic matter, $0.8 \% \mathrm{~N}, 100 \mathrm{mg} \mathrm{P} \cdot \mathrm{L}^{-1}, 423 \mathrm{mg} \mathrm{K} \cdot \mathrm{L}^{-1}$, $7.3 \mathrm{mg} \mathrm{Fe} \cdot \mathrm{L}^{-1}, 4 \mathrm{mg} \mathrm{Zn} \cdot \mathrm{L}^{-1}$ and $29 \mathrm{mg} \mathrm{Cu} \cdot \mathrm{L}^{-1}$. Each of the four replicate pots contained five plants. Fifteen days after emergence, irrigation water treatments were applied. Treatments were (1) Control: deionised water alone; (2) Saline (salinity stress): $150 \mathrm{mM}$ $\mathrm{NaCl}$; (3) [Saline $+\mathrm{Ca}_{50}$ ]: $150 \mathrm{mM} \mathrm{NaCl}+50$ $\mathrm{mM} \mathrm{Ca}$, (4) [Saline $\left.+\mathrm{Ca}_{100}\right]: 150 \mathrm{mM} \mathrm{NaCl}$ $+100 \mathrm{mM} \mathrm{Ca}$, and (5) [Saline $+\mathrm{Ca}_{150}$ ]: 150 $\mathrm{mM} \mathrm{NaCl}+150 \mathrm{mM} \mathrm{Ca}$. Calcium was supplied as $\mathrm{CaSO}_{4}$. Plants were harvested $45 \mathrm{~d}$ after treatments.

\subsection{Chlorophyll determination}

Prior to extraction, fresh leaf samples were cleaned with deionised water to remove any surface contamination. Chlorophyll extraction was carried out on fresh, fully expanded leaf material; a 1-g leaf sample was ground 
in $90 \%$ acetone using a pestle and mortar. The absorbance was measured with a UV/ visible spectrophotometer (UV-160 A) and chlorophyll concentrations were calculated using the equation proposed by Strain and Svec [21]: $\mathrm{Chl}_{\mathrm{a}}\left(\mathrm{mg} \cdot \mathrm{mL}^{-1}\right)=[11.64 \times$ $\left.\left(\mathrm{A}_{663}\right)\right]-\left[2.16 \times\left(\mathrm{A}_{645}\right)\right]$ and $\mathrm{Chl}_{\mathrm{b}}\left(\mathrm{mg} \cdot \mathrm{mL}^{-1}\right)$ $=\left[20.97 \times\left(\mathrm{A}_{645}\right)\right]-\left[3.94 \times\left(\mathrm{A}_{663}\right)\right]$, where $\left(\mathrm{A}_{663}\right)$ and $\left(\mathrm{A}_{645}\right)$ represent absorbance values read at $663 \mathrm{~nm}$ and $645 \mathrm{~nm}$ wavelengths, respectively.

\subsection{Electrolyte leakage}

Measurement of electrolyte leakage was included in order to obtain more information on the membrane stability and, thereby, the relative ion content in the apoplastic space. Electrolyte leakage was assessed as described by Lutts et al. [22] using eight young leaf discs for each treatment. Samples were washed three times with deionised water to remove surface-adhered electrolytes. Leaf discs were placed in closed vials containing $10 \mathrm{~mL}$ of deionised water and incubated at $25^{\circ} \mathrm{C}$ on a rotary shaker for $24 \mathrm{~h}$; subsequently, electrical conductivity of the solution $\left(\mathrm{L}_{\mathrm{t}}\right)$ was determined. Samples were then autoclaved at $120{ }^{\circ} \mathrm{C}$ for $20 \mathrm{~min}$ and the last electrical conductivity $\left(\mathrm{L}_{0}\right)$ was obtained after equilibration at $25^{\circ} \mathrm{C}$. The electrolyte leakage was defined as follows: Electrolyte leakage $(\%)=\left[\left(\mathrm{L}_{\mathrm{t}} / \mathrm{L}_{0}\right) \times 100\right]$.

\subsection{Relative water content}

Leaf relative water content (LRWC) was measured using the method of Yamasaki and Dillenburg [23]. Leaves were sampled from the midsection of each plant in order to minimise the age effect on variability of results. Individual leaves were first removed from the stem and then weighed to obtain fresh mass $\left(\mathrm{F}_{\text {Mass }}\right)$. In order to determine the turgid mass $\left(\mathrm{T}_{\text {Mass }}\right.$ ), whole leaves were floated in distilled water inside a closed petri dish. During the imbibition period, leaf samples were weighed periodically after the water was gently blotted from the leaf surface with tissue paper. At the end of the imbibition period, leaf samples were placed in a pre-heated oven at $80{ }^{\circ} \mathrm{C}$ for $48 \mathrm{~h}$ in order to obtain dry mass $\left(\mathrm{D}_{\text {Mass }}\right)$. All mass measurements were made using an analytical scale with precision of $0.0001 \mathrm{~g}$. Values of $\mathrm{F}_{\text {Mass }}, \mathrm{T}_{\text {mass }}$ and $\mathrm{D}_{\text {Mass }}$ were used to calculate LRWC using the equation: LRWC(\%) $=\left[\left(\mathrm{F}_{\text {Mass }}-\mathrm{D}_{\text {Mass }}\right) /\left(\mathrm{T}_{\text {Mass }}-\mathrm{D}_{\text {Mass }}\right)\right] \times 100$.

\subsection{Dry weight determinations and chemical analysis}

Two randomly selected plants per replicate were divided into shoots and roots and dried in an oven at $70{ }^{\circ} \mathrm{C}$ for $2 \mathrm{~d}$ to determine dry weights and elemental concentrations. Chemical analyses were carried out on a dry-weight basis. Ground samples were dry-ashed at $550{ }^{\circ} \mathrm{C}$ for $4 \mathrm{~h}$, mixed with $2 \mathrm{M}$ hot $\mathrm{HCl}$, filtered, and then brought to a final volume of $50 \mathrm{~mL}$ with distilled water. Calcium, $\mathrm{K}$ and $\mathrm{Na}$ were determined in these sample solutions using an Eppendorf flame photometer [24].

\subsection{Statistical Analysis}

Each pot was considered as a replicate and the five treatments were repeated four times for each cultivar for a total of 40 pots. Data were analysed using the analysis of variance (ANOVA) program of SAS [25]. Statistically different groups were determined by least significant difference (LSD) $(P<0.05)$.

\section{Results and discussion}

\subsection{Effects of $\mathrm{CaSO}_{4}$ on seed germination and seedling growth}

Effects of the addition of $\mathrm{CaSO}_{4}$ to $150 \mathrm{mM}$ $\mathrm{NaCl}$ solution of $-0.7 \mathrm{MPa}$ on seed germination $\left(\mathrm{G}_{\mathrm{F} \%}\right)$ and seedling growth $\left(\mathrm{S}_{\mathrm{F} \%}\right)$ were examined in both rootstocks (table I). In the Ghazvini rootstock, both $\mathrm{G}_{\mathrm{F} \%}$ and $\mathrm{S}_{\mathrm{F} \%}$ were higher than in the Badami-e-zarand rootstock, for all treatments. In the $\mathrm{NaCl}$ (saline) treatment alone, both $\mathrm{G}_{\mathrm{F} \%}$ and $\mathrm{S}_{\mathrm{F} \%}$ were the lowest. $G_{\mathrm{F} \%}$ was significantly lower at the highest $\mathrm{CaSO}_{4}$ concentration. At $0 \mathrm{mM}$ $\mathrm{CaSO}_{4}$, all seedlings showed abnormalities, but at $150 \mathrm{mM} \mathrm{CaSO}_{4}$, although many seedlings showed abnormalities, the degrees of 


\begin{tabular}{|c|c|c|c|c|}
\hline \multirow[t]{2}{*}{ Treatments $^{1}$} & \multicolumn{2}{|c|}{ Ghazvini } & \multicolumn{2}{|c|}{ Badami-e-zarand } \\
\hline & Germination $_{\mathrm{F} \%}$ & Seedling $_{\mathrm{F} \%}$ & Germination $_{\mathrm{F} \%}$ & Seedling $_{\mathrm{F} \%}$ \\
\hline Control & $93 \mathrm{a}$ & $80 a$ & $85 a$ & $63 a$ \\
\hline Saline & $40 \mathrm{~b}$ & $33 \mathrm{~b}$ & $8 \mathrm{c}$ & $0 \mathrm{c}$ \\
\hline Saline $+\mathrm{Ca}_{50}$ & $78 \mathrm{a}$ & $75 a$ & $49 \mathrm{~b}$ & $38 \mathrm{~b}$ \\
\hline Saline $+\mathrm{Ca}_{100}$ & $80 a$ & $76 \mathrm{a}$ & $53 \mathrm{~b}$ & $38 \mathrm{~b}$ \\
\hline Saline $+\mathrm{Ca}_{150}$ & $46 \mathrm{~b}$ & $38 \mathrm{~b}$ & $13 c$ & $6 c$ \\
\hline
\end{tabular}

the abnormalities were less conspicuous than those observed at $0 \mathrm{mM} \mathrm{CaSO}_{4}$. Abnormalities in radicles were higher than those in plumules of seedlings. Both $\mathrm{G}_{\mathrm{F} \%}$ and $\mathrm{S}_{\mathrm{F} \%}$ were significantly increased by increasing $\mathrm{CaSO}_{4}$ concentration, except at the highest $\mathrm{CaSO}_{4}$ concentration. At (50 and 100) mM $\mathrm{CaSO}_{4}$, most seedlings appeared normal (white and straight).

In $\mathrm{CaSO}_{4}$ treatments, although $\mathrm{Ca}^{2+}$ movement into the seedlings was more limited than inward movement of $\mathrm{Na}^{+}$in treatment with $\mathrm{NaCl}, \mathrm{G}_{\mathrm{F} \%}$ of seeds treated with $\mathrm{CaSO}_{4}$ was higher than in $\mathrm{NaCl}$ treatment alone. This would be attributable, at least partly, to the action of $\mathrm{Ca}^{2+}$ in decreasing the permeability of many ion channels [26], thus reducing efflux of intracellular solutes and maintaining a low $\Psi_{\mathrm{W}}$ of seedling water. A more strict discussion of the osmotic effects of salt on seed germination needs to be based on actual $\Psi_{\mathrm{W}}$ values. Differences in the characteristics of inward and outward movements of ions, and differences in the effects of salt on cell wall extensibility and/ or water conductance of membranes may have caused the different responses of $\mathrm{G}_{\mathrm{F} \%}$ and $\mathrm{S}_{\mathrm{F} \%}$ of $P$. vera to salt.

Low concentrations of $\mathrm{Ca}^{2+}$ favoured seed germination, seedling water uptake and seedling growth of $P$. vera in $\mathrm{NaCl}$ treatment (tables I, II). They are believed to be attributable to an interaction of $\mathrm{Ca}^{2+}$ and salt components. In $\mathrm{NaCl}$ treatment, the addition of low concentrations of $\mathrm{Ca}^{2+}$ reduced $\mathrm{K}^{+}$leakage from both cultivars of P. vera (data not shown). Similar results have been reported for crop plants [9] and charocean macroalgae [27], for both of which $\mathrm{K}^{+}$leakage from plant cells treated with $\mathrm{NaCl}$ was reduced by adding $\mathrm{Ca}^{2+}$ to the medium. On the other hand, the addition of low concentrations of $\mathrm{Ca}^{2+}$ did not cause any appreciable reduction in the permeation of $\mathrm{Na}^{+}$into $P$. vera seedlings in $\mathrm{NaCl}$ treatment (data not shown). This is in contrast to the results with crop plants [11, $28,29]$ and charocean algae [27, 30], for which $\mathrm{Na}^{+}$permeation into the plant cells treated with $\mathrm{NaCl}$ was reduced by adding $\mathrm{Ca}^{2+}$ to the medium. The primitive effects of $\mathrm{Ca}^{2+}$ on seed germination and seedling growth of $P$. vera, especially in the Ghazvini rootstock in salt treatments, would have resulted, at least partly, from reduced efflux of $\mathrm{K}^{+}$(and possibly other solutes) from the seedlings, and eventual maintenance of a low $\Psi_{\mathrm{W}}$ of seedling water. Additionally, it is possible that $\mathrm{Ca}^{2+}$ alleviated the reduction in cell wall extensibility caused by salts and/or water conductance of the plasma membrane $[13,14]$ in $P$. vera cv. Ghazvini seedlings, thus favouring water uptake and extension growth. Alleviatory effects of $\mathrm{Ca}^{2+}$ on the toxicity of $\mathrm{Na}^{+}$ 


\begin{tabular}{|c|c|c|c|c|}
\hline \multirow[t]{2}{*}{ Rootstock } & \multirow[t]{2}{*}{ Treatments $^{1}$} & \multirow{2}{*}{$\begin{array}{l}\text { Relative water content } \\
\text { (\%) }\end{array}$} & Shoot dry weight & Root dry weight \\
\hline & & & \multicolumn{2}{|c|}{$g \cdot$ plant $^{-1}$} \\
\hline \multicolumn{5}{|l|}{ Ghazvini } \\
\hline & Control & $90 \mathrm{a}$ & $1.11 \mathrm{ab}$ & $0.63 \mathrm{a}$ \\
\hline & Saline & $73 \mathrm{~b}$ & $0.70 \mathrm{c}$ & $0.47 \mathrm{~b}$ \\
\hline & Saline $+\mathrm{Ca}_{50}$ & $86 \mathrm{a}$ & $1.00 \mathrm{abc}$ & $0.52 a b$ \\
\hline & Saline $+\mathrm{Ca}_{100}$ & $86 \mathrm{a}$ & $1.20 \mathrm{a}$ & $0.61 \mathrm{a}$ \\
\hline & Saline $+\mathrm{Ca}_{150}$ & $75 \mathrm{~b}$ & $0.78 \mathrm{bc}$ & $0.49 \mathrm{~b}$ \\
\hline \multicolumn{5}{|c|}{ Badami-e-zarand } \\
\hline & Control & $91 \mathrm{a}$ & $1.88 \mathrm{a}$ & $0.90 \mathrm{a}$ \\
\hline & Saline & $70 d$ & $0.88 \mathrm{c}$ & $0.46 \mathrm{c}$ \\
\hline & Saline $+\mathrm{Ca}_{50}$ & $78 \mathrm{c}$ & $1.16 \mathrm{bc}$ & $0.55 \mathrm{bc}$ \\
\hline & Saline $+\mathrm{Ca}_{100}$ & $86 \mathrm{~b}$ & $1.40 \mathrm{~b}$ & $0.66 \mathrm{~b}$ \\
\hline & Saline $+\mathrm{Ca}_{150}$ & $70 \mathrm{~d}$ & $0.83 \mathrm{c}$ & $0.47 \mathrm{c}$ \\
\hline
\end{tabular}

and $\mathrm{Mg}^{2+}$ on radicles have been found in previous studies with a halophyte Kalidium capsicum [5] and three non-halophytes. $\mathrm{Ca}^{2+}$ in the medium allowed normal seedling development [9]. Because $\mathrm{Na}^{+}$ influx into P. vera (cv. Ghazvini and Badami-e-zarand) seedlings was decreased by $\mathrm{Ca}^{2+}$, the abnormalities of $\mathrm{Na}^{+}$-treated seedlings would not have resulted from cytosolic $\mathrm{Na}^{+}$accumulation. This is in agreement with the situation in $\mathrm{NaCl}$ treated charocean algae, in which $\mathrm{Ca}^{2+}$ alleviated salt toxicity by decreasing $\mathrm{Na}^{+}$influx into the cells [27]. In addition to cations, anions seem to also affect seed germination of $P$. vera, although they did not cause any appreciable effect on seedling growth. The effect of $\mathrm{SO}_{4}^{2-}$ and suppressive effect of $\mathrm{Cl}^{-}$ on seed germination were found in K. capsicum [5] as well as in P. vera in this study. However, because the $\Psi_{\mathrm{W}}$ values presented in this study may deviate from the actual $\Psi_{\mathrm{W}}$ values of the salt solutions, the possibility cannot be ruled out that this result was caused by larger deviations of calculated values of $\Psi_{\mathrm{W}}$ in $\mathrm{SO}_{4}^{2-}$ salts than in $\mathrm{Cl}^{-}$salts. Further research is needed to clarify the effects of anions on seed germination.

\subsection{Evaluation of salinity $+\mathrm{CaSO}_{4}$ on seedlings}

\subsubsection{Relative water content and plant growth}

Salt treatment reduced dry matter and leaf relative water content in cv. Badami-ezarand, compared with the control treatment, but it did not cause significant reductions in these parameters in $\mathrm{cv}$. Ghazvini (table II). Inhibition of plant growth under saline conditions may be due to either osmotic reduction in water availability or excessive ion ( $\mathrm{Na}$ and $\mathrm{Cl}$ ) accumulation in plant tissues. The decrease in leaf relative water content under salinity stress in wheat has already been reported. This decrease indicates a loss of turgor that results in limited water availability for the cell-extension process [31]. 


\begin{tabular}{|c|c|c|c|c|}
\hline \multirow[t]{2}{*}{ Rootstock } & \multirow[t]{2}{*}{ Treatments $^{1}$} & Chlorophyll a & Chlorophyll $b$ & \multirow{2}{*}{$\begin{array}{c}\text { Electrolyte } \\
\text { leakage } \\
(\%)\end{array}$} \\
\hline & & \multicolumn{2}{|c|}{$\mathrm{mg} \cdot \mathrm{kg}^{-1}$} & \\
\hline \multicolumn{5}{|l|}{ Ghazvini } \\
\hline & Control & $616 \mathrm{a}$ & $218 c$ & $20 \mathrm{a}$ \\
\hline & Saline & $610 a$ & $199 d$ & $24 \mathrm{a}$ \\
\hline & Saline $+\mathrm{Ca}_{50}$ & $618 a$ & $275 a$ & $23 a$ \\
\hline & Saline $+\mathrm{Ca}_{100}$ & $584 \mathrm{~b}$ & $259 \mathrm{~b}$ & $14 \mathrm{~b}$ \\
\hline & Saline $+\mathrm{Ca}_{150}$ & $572 \mathrm{~b}$ & $220 c$ & $20 \mathrm{a}$ \\
\hline \multicolumn{5}{|c|}{ Badami-e-zarand } \\
\hline & Control & $752 \mathrm{c}$ & $328 \mathrm{~b}$ & $19 d$ \\
\hline & Saline & 742 c & $306 \mathrm{c}$ & $51 \mathrm{a}$ \\
\hline & Saline $+\mathrm{Ca}_{50}$ & 790 a & $345 a$ & $45 \mathrm{bc}$ \\
\hline & Saline $+\mathrm{Ca}_{100}$ & $770 \mathrm{~b}$ & $310 \mathrm{c}$ & $41 \mathrm{~b}$ \\
\hline & Saline $+\mathrm{Ca}_{150}$ & $749 c$ & $305 \mathrm{c}$ & $47 c$ \\
\hline
\end{tabular}

Calcium sulphate significantly improved these parameters when added to the salinity treatment at both levels (saline $+\mathrm{Ca}_{50}$ and saline $+\left(\mathrm{Ca}_{100}\right)$, but values remained lower than those obtained in the control treatments for both cv. Ghazvini and Badami-ezarand. It was suggested that the addition of Ca to the root environment of $\mathrm{NaCl}$-stressed plants would help organic solute accumulation in the roots, which could contribute to root osmotic adjustment, in turn favouring the maintenance of plant-water balance and growth [32].

\subsubsection{Chlorophyll and electrolyte leakage}

Chlorophyll contents have been suggested as one of the parameters of salt tolerance in crop plants [31, 33]. The adverse effect of high $\mathrm{NaCl}$ on chlorophyll concentration has been shown previously for rice and barley [34]. In our experiments, cv. Badami-ezarand had more chlorophyll than cv. Ghazvini under both stressed and normal conditions. Calcium sulphate at $50 \mathrm{mM}$ concen- tration could increase total chlorophyll significantly in both cultivars (table III). Total chlorophyll content declined significantly with salinity treatment alone. Chlorophyll $a$ and chlorophyll $b$ had no clear trend.

Membrane permeability was determined by measuring electrolyte leakage. The high treatment $(150 \mathrm{mM} \mathrm{NaCl})$ induced significant increases in electrolyte leakage in cv. Ghazvini and Badami-e-zarand, compared with the control plants (table III). Similar results were obtained by Lutts et al. [22], who reported that high salt concentration increased the membrane permeability of sensitive rice varieties and strawberry, respectively. The cellular membrane dysfunction due to stress is well expressed in its increased permeability for ions and electrolytes, which can be readily measured by the efflux of electrolytes [22].

Addition of calcium sulphate partially maintained membrane permeability in the Badami-e-zarand rootstock, but only fully restored it to control levels in the Ghazvini rootstock with moderate calcium sulphate 
$\left(\right.$ saline $\left.+\mathrm{Ca}_{100}\right) \quad($ table III $)$. Because $\mathrm{Ca}$ appears to be readily displaced from its membrane binding sites by other cations, these functions may become seriously impaired by reduced $\mathrm{Ca}$ availability. Increasing the external concentration of Ca largely counteracted this displacement [31].

\subsubsection{Mineral nutrients}

\subsubsection{Sodium content}

The impact of the salinity stress on $\mathrm{Na}$ itself within plants is not unexpected, with very large elevations in $\mathrm{Na}$ concentrations in both the leaves and, especially, the roots. When compared with control values, addition of $\mathrm{CaSO}_{4}$ had a relatively modest effect on reducing $\mathrm{Na}$ elevation, but, obviously, this reduction is sufficient to significantly restore the key growth to levels approaching those for unstressed plants (table IV). These data are in agreement with those produced by other authors for other crop species; for example, tomato [36], rice [37] and plum [38].

\subsubsection{Potassium content}

Our experiments showed that saline treatment greatly reduced shoot $\mathrm{K}$ concentrations in cv. Badami-e-zarand rootstock, but not in $\mathrm{cv}$. Ghazvini, compared with unstressed plants (table $I V$ ). In saline soils, $\mathrm{Na}$ competes with $\mathrm{K}$ for uptake across the plasma membrane of plant cells. This can result in high $[\mathrm{Na}: \mathrm{K}]$ ratios that reduce plant growth and eventually become toxic [39]. Our results show that the salt-sensitive rootstock, cv. Badami-e-zarand, had much higher $[\mathrm{Na}: \mathrm{K}]$ ratios than the salt-tolerant $\mathrm{cv}$. Ghazvini under salt treatments (table IV).

Addition of $\mathrm{Ca}$ to the rooting medium increased $\mathrm{K}$ and reduced $\mathrm{Na}$ concentrations in leaves of the Badami-e-zarand rootstock; in $\mathrm{cv}$. Ghazvini, it did not cause further increases in leaf $\mathrm{K}$. A possible reason for why, even under saline conditions, the addition of $\mathrm{Ca}$ did not increase leaf $\mathrm{K}$ in cv. Ghazvini could be that the uptake of $\mathrm{K}$ in this rootstock was not restricted. The presence of adequate $\mathrm{Ca}$ in the substrate improves the $[\mathrm{K}: \mathrm{Na}]$ ratio selectivity by shifting the uptake

Table IV.

Sodium, potassium, [Na:K] ratios and calcium in leaves and roots of pistachio rootstock seedlings differing in salinity tolerance, grown under salinity conditions in the presence of different concentrations of calcium sulphate.

\begin{tabular}{|c|c|c|c|c|c|c|c|c|}
\hline \multirow[t]{3}{*}{ Rootstock } & \multirow[t]{3}{*}{ Treatments $^{1}$} & \multicolumn{4}{|c|}{ Leaf } & \multicolumn{3}{|c|}{ Root } \\
\hline & & $\mathrm{Ca}$ & $\mathrm{Na}$ & $\mathrm{K}$ & \multirow[t]{2}{*}[\mathrm{Na}:\mathrm{K}]{} & $\mathrm{Ca}$ & $\mathrm{Na}$ & $\mathrm{K}$ \\
\hline & & \multicolumn{3}{|c|}{$\mathrm{mM} \cdot \mathrm{kg}^{-1}$} & & \multicolumn{3}{|c|}{$\mathrm{mM} \cdot \mathrm{kg}^{-1}$} \\
\hline \multicolumn{9}{|l|}{ Ghazvini } \\
\hline & Control & $342 \mathrm{~b}$ & $30 \mathrm{~d}$ & $508 \mathrm{a}$ & 0.06 & $342 \mathrm{bc}$ & $193 d$ & 228 a \\
\hline & Saline & $310 \mathrm{c}$ & 366 a & $490 \mathrm{ab}$ & 0.75 & $315 d$ & $579 a$ & $128 \mathrm{~b}$ \\
\hline & Saline $+\mathrm{Ca}_{50}$ & $338 \mathrm{~b}$ & $260 \mathrm{~b}$ & $481 \mathrm{bc}$ & 0.54 & $336 \mathrm{c}$ & $589 a$ & $108 \mathrm{~b}$ \\
\hline & Saline $+\mathrm{Ca}_{100}$ & $357 \mathrm{~b}$ & $180 \mathrm{c}$ & $464 \mathrm{~cd}$ & 0.39 & $358 \mathrm{ab}$ & $526 \mathrm{~b}$ & $83 \mathrm{c}$ \\
\hline & Saline $+\mathrm{Ca}_{150}$ & $380 \mathrm{a}$ & $153 \mathrm{c}$ & $448 d$ & 0.34 & $370 \mathrm{a}$ & $493 \mathrm{c}$ & $100 \mathrm{bc}$ \\
\hline \multicolumn{9}{|c|}{ Badami-e-zarand } \\
\hline & Control & $218 a$ & $45 \mathrm{e}$ & $544 \mathrm{a}$ & 0.08 & $400 \mathrm{c}$ & $276 \mathrm{~d}$ & $173 \mathrm{a}$ \\
\hline & Saline & $138 \mathrm{c}$ & $1772 \mathrm{a}$ & $390 \mathrm{c}$ & 4.54 & $463 \mathrm{~b}$ & 2570 a & $117 \mathrm{c}$ \\
\hline & Saline $+\mathrm{Ca}_{50}$ & $160 \mathrm{~b}$ & $1332 \mathrm{~b}$ & $466 \mathrm{~b}$ & 2.86 & $477 \mathrm{~b}$ & $2020 \mathrm{~b}$ & $189 a$ \\
\hline & Saline $+\mathrm{Ca}_{100}$ & $168 \mathrm{~b}$ & $1118 \mathrm{c}$ & $477 \mathrm{~b}$ & 2.34 & $499 a$ & $1291 \mathrm{c}$ & $168 b$ \\
\hline & Saline $+\mathrm{Ca}_{150}$ & $173 \mathrm{~b}$ & $980 \mathrm{~d}$ & $487 \mathrm{~b}$ & 2.01 & $510 a$ & $1243 c$ & $170 \mathrm{a}$ \\
\hline
\end{tabular}

${ }^{1}$ Saline: $150 \mathrm{mM} \mathrm{NaCl} ; \mathrm{Ca}_{50}: 50 \mathrm{mM} \mathrm{CaSO}_{4} ; \mathrm{Ca}_{100}: 100 \mathrm{mM} \mathrm{CaSO}{ }_{4} ; \mathrm{Ca}_{150}: 150 \mathrm{mM} \mathrm{CaSO}_{4}$.

For the same rootstock, values followed by different letters within the same column are significantly different at $P \leq 0.05$ (LSD test). 
ratio in favour of $\mathrm{K}$ at the expense of $\mathrm{Na}$. Likewise, $\mathrm{K}$ levels increased and $\mathrm{Na}$ decreased in Troyer citrange roots with the addition of $\mathrm{Ca}$ to the saline substrate [40].

\subsubsection{Calcium content}

High $\mathrm{NaCl}$ reduced leaf $\mathrm{Ca}$ concentration in Ghazvini and Badami-e-zarand rootstocks (table IV). The uptake of Ca from the substrate may be depressed because of ion interactions, precipitation and increases in ionic strength. These factors reduce the activity of $\mathrm{Ca}$ in solution, thereby decreasing Ca availability to the plant [41]. The results of our study also showed that supplemental $\mathrm{Ca}$ reduced leaf $\mathrm{Na}$ (table IV). Calcium was found to be effective at reducing the transport of sodium from roots to leaves, thereby alleviating foliar injury in citrus grown under saline conditions [42, 43].

\subsubsection{Assessment of salt tolerance in pistachio rootstocks}

Salt tolerance is usually assessed as the percent biomass production in saline versus control conditions over a prolonged period of time. Reductions in total dry matter were much lower in $\mathrm{cv}$. Ghazvini than in $\mathrm{cv}$. Badami-e-zarand under salinity treatment compared with the control treatment. Some researchers have reported that there is a negative relationship between salt tolerance and $\mathrm{Na}$ in plant shoots in some plant species [44, 45]; moreover, the salt-tolerant plants generally exclude $\mathrm{Na}$ from their shoots to prevent $\mathrm{Na}$ accumulation in the leaves [46]. The plant materials used in our experiment showed an inverse relationship between salt tolerance and $\mathrm{Na}$ concentration in leaves. There are no statistical comparisons between the rootstocks presented, but, apparently, cv. Ghazvini had much lower $\mathrm{Na}$ and higher $\mathrm{Ca}$ and $\mathrm{K}$ in the leaves than $\mathrm{cv}$. Badami-e-zarand under salinity stress. Similarly, in Triticeae plants, the degree to which plants tolerated salt stress was linked to their capacity to maintain higher $\mathrm{K}$ and lower Na levels in their leaves than salt-sensitive rootstocks [47]. High Ca concentration can reduce the permeability of the plasma membranes to Na. The reduction in membrane permeability to $\mathrm{Na}$ by $\mathrm{Ca}$ reduces the accumulation of $\mathrm{Na}$ by passive influx [9].
The restriction of Na accumulation and both $\mathrm{Ca}$ and $\mathrm{K}$ enhancement in leaves might be a mechanism by which Ghazvini copes with salinity in the root zone.

\section{Conclusions}

From the results of our experiments, it can be concluded that:

(1) High $\mathrm{NaCl}$ in nutrient solution can strongly affect plant growth, chlorophyll content, relative water content and membrane permeability.

(2) Added calcium sulphate may ameliorate the parameters affected by high salinity (e.g., plant growth, membrane permeability) and may reduce $\mathrm{Na}$, but it increases $\mathrm{Ca}$ and $\mathrm{K}$ concentrations in shoots and roots of salt-stressed rootstocks.

(3) The Ghazvini rootstock was more tolerant to salinity than the Badami-e-zarand rootstock. The restriction of $\mathrm{Na}$ accumulation and the enhancement of both $\mathrm{Ca}$ and $\mathrm{K}$ in leaves might be a mechanism by which $\mathrm{cv}$. Ghazvini copes with salinity in the rooting medium.

\section{References}

[1] Grattan S.R., Grieve C.M., Salinity-mineral nutrient relations in horticultural crops, Sci. Hortic. 78 (1999) 127-157.

[2] Greenway H., Munns R., Mechanisms of salt tolerance in nonhalophytes, Annu. Rev. Plant Physiol. 31 (1980) 149-190.

[3] Marschner H., Mineral nutrition of higher plants, Acad. Press, London, UK, 1995.

[4] Hardegree S.P., Emmerich W.E., Partitioning water potential and specific salt effects on seed germination of four grasses, Ann. Bot. 66 (1990) 587-595.

[5] Tobe K., Li X., Omasa K., Effects of sodium, magnesium and calcium salts on seed germination and radicle survival of a halophyte, Kalidium capsicum (Chenopodiaceae), Aust. J. Bot. 50 (2002) 163-169.

[6] Shannon M.C., Breeding, selection, and the genetics of salt tolerance, in: Staples R.C. 
(Ed.), Salinity tolerance in plants: strategies for crop improvement, Wiley, New York, USA, 1984, pp. 231-254.

[7] Bliss R.D., Platt-Aloia K.A., Thomson W.W., The inhibitory effect of $\mathrm{NaCl}$ on barley germination, Plant Cell Environ. 9 (1986) 727-733.

[8] LaHaye P.A., Epstein E., Salt toleration by plants: enhancement with calcium, Sci. 166 (1969) 395-396.

[9] Cramer G.R., Lauchli A., Polito V.S., Displacement of $\mathrm{Ca}^{2+}$ by $\mathrm{Na}^{+}$from the plasmalemma of root cells. A primary response to salt stress? Plant Physiol. 79 (1985) 207-211.

[10] Cramer G.R., Sodium-calcium interactions under salinity stress, in: Lauchli A., Lüttge $U$. (Eds.), Salinity: environment - plants - molecules, Klüwer Acad. Publ., Dordrecht, Holl., 2002, pp. 205-227.

[11] Allen G.J., Wyn Jones R.G., Leigh R.A., Sodium transport measured in plasma membrane vesicles isolated from wheat genotypes with differing $\mathrm{K}^{+} / \mathrm{Na}^{+}$discrimination traits, Plant Cell Environ. 18 (1995) 105-115.

[12] Nabil M., Coudret A., Effects of sodium chloride on growth, tissue elasticity and solute adjustment in two Acacia nilotica subspecies, Physiol. Plantarum 93 (1995) 217-224.

[13] Azaizeh H., Gunse B., Steudle E., Effects of $\mathrm{NaCl}$ and $\mathrm{CaCl}_{2}$ on water transport across root cells of maize (Zea mays L.) seedlings, J. Plant Physiol. 99 (1992) 886-894.

[14] Cramer G.R., Kinetics of maize leaf elongation. 2. Response of a Na-excluding cultivar and a Na-including cultivar to varying $\mathrm{Na} / \mathrm{Ca}$ salinities, J. Exp. Bot. 43 (1992) 857-864.

[15] Busch D.S., Calcium regulation in plant cell and its role in signaling, Annu. Rev. Plant Physiol. 46 (1995) 95-122.

[16] Hasegawa P., Bressan R.A., Zhu J. K., Bohnert H.J., Plant cellular and molecular responses to high salinity, Annu. Rev. Plant Mol. Biol. 51 (2000) 463-499.

[17] Alkhani H., Ghorbani M., A contribution to the halophytic vegetation and flora of Iran, in: Lieth H., Al Massoum A. (Eds.), Towards the rational use of high salinity tolerance plants, Kluwer Acad. Publ., Dordrecht, Neth., vol. 1, 1992, pp. 35-44.

[18] Behboudian M.H., Walker R.R., Torokfaivy E., Effects of water stress and salinity on photosynthesis of pistachio, Sci. Hortic. 29 (1986) 251-261.
[19] Picchioni G.A., Miyamota S., Salt effects on growth and ion uptake of pistachio rootstock seedlings, J. Am. Soc. Hortic. Sci. 115 (1990) 647-653.

[20] Ferguson L., Poss J.A., Grattan S.R., Grieve C.M., Wang D., Wilson C., Donovan Chao C.T., Pistachio rootstocks influence scion growth and ion relations under salinity and boron stress, J. Am. Soc. Hortic. Sci. 127 (2002) 194-199.

[21] Strain H.H., Svec W.A., Extraction, separation, estimation and isolation of chlorophylls, in: Vernon L.P., Seely G.R. (Eds.),The chlorophylls, Acad. Press, New York, USA, 1996, 21-66.

[22] Lutts S., Kinet J.M., Bouharmont J., NaClinduced senescence in leaves of rice (Oryza sativa L.) cultivars differing in salinity resistance, Ann. Bot. 78 (1996) 389-398.

[23] Yamasaki S., Dillenburg L.C., Measurments of leaf relative water content in Araucaria angustifolia, Rev. Bras. Fisiol. Veg. 11 (1999) 69-75.

[24] Chapman H.D., Pratt P.F., Methods of plant analysis, in: Chapman H.D., Pratt P.F. (Eds.), Methods of analysis for soils, plants and water, Acad. Press, Riverside, CA, USA, 1982, pp. 60-193.

[25] Anon., STAT User's Guide, Version 6.11, Vol. 1., Stat. Anal. Syst. Inst., Cary, NC, USA, 1996.

[26] Tyerman S.D., Skerrett I.M., Root ion channels and salinity, Sci. Hortic. 78 (1999) 175235 .

[27] Tufariello J.A.M., Hoffmann R., Bisson M.A., The effect of divalent cations on $\mathrm{Na}^{+}$tolerance in charophytes. II. Chara coralline, Plant Cell Environ. 11 (1988) 473-479.

[28] Roberts S.K., Tester M., Permeation of $\mathrm{Ca}^{2+}$ and monovalent cations through an outwardly rectifying channel in maize root stelar cells, J. Exp. Bot. 48 (1997) 839-846.

[29] Tyerman S.D., Skerrett I.M., Garrill A., Findlay G.P., Leigh R.A., Pathways for the permeation of $\mathrm{Na}^{+}$and $\mathrm{Cl}^{-}$into protoplasts derived from the cortex of wheat roots, J. Exp. Bot. 48 (1997) 459-480.

[30] Hoffmann R., Tufariello J., Bisson M.A., Effect of divalent cations on $\mathrm{Na}^{+}$permeability of Chara coralline and freshwater grown Chara buckellii, J. Exp. Bot. 40 (1989) 875-881. 
[31] Srivastava T.P., Gupta S.C., Lal P., Muralia P.N., Kumar A., Effect of salt stress on physiological and biochemical parameters of wheat, Ann. Arid Zone 27 (1998) 197-204.

[32] Giriji C., Smith B.N., Swamy P.M., Interactive effects of sodium chloride and calcium chloride on the accumulation of praline and glycine betaine in peanut (Arachis hypogaea L.), Environ. Exp. Bot. 472002 1-10.

[33] Hernandez J.A., Olmos E., Corpas F.J., Sevilla F., Del Rio L.A., Salt induced oxidative stress in chloroplasts of pea plants, Plant Sci. 105 (1995) 151-167.

[34] Belkhodja R., Morales F., Abadia A., GomezAparisi J., Abadia J., Chlorophyll fluorescence as a possible tool for salinity tolerance screening in barley (Hordeum vulgare L.), J. Plant Physiol. 104 (1994) 667-673.

[35] Lynch J., Lauchli A., Salinity affects intracellular calcium in corn root protoplasts, Plant Physiol. 87 (1988) 351-356.

[36] Satti S.M.E., Al-Yahyai R.A., Salinity tolerance in tomato: implications of potassium, calcium and phosphorus. Commun. Soil Sci. Plant Anal. 26 (17 \& 18) (1995) 2749-2760.

[37] Asch F., Dingkuhn M., Wittstock C., Doerffling K., Sodium and potassium uptake of rice panicles as affected by salinity and season in relation to yield and yield components, Plant Soil 207 (1999) 133-145.

[38] Bolat I., Kaya C., Almaca A., Timucin S., Calcium sulfate improves salinity tolerance in rootstocks of plum, J. Plant Nutr. 29 (2006) 553-564.
[39] Schachtman D., Lio W., Molecular pieces to the puzzle of the interaction between potassium and sodium uptake in plants, Trends Plant Sci. 4 (1999) 281-287.

[40] Banuls J., Legaz F., Primo-Millo E., Salinitycalcium interactions on growth and ionic concentration of citrus plants, Plant Soil 133 (1991) 39-46.

[41] Suarez D.L., Grieve C.M., Predicting cation ratios in corn from saline solution composition, J. Exp. Bot. 39 (1988) 605-612.

[42] Banuls J., Serna M.D., Legaz F., Talon M., Primo-Millo E., Growth and gas exchange parameters of citrus plants stressed with different salts, J. Plant Physiol. 150 (1997) 194199.

[43] Zekri M,, Parsons L.R., Salinity tolerance of citrus rootstocks: effects of salt on root and leaf mineral concentrations, Plant Soil 147 (1992) 171-181.

[44] Gorham J., WynJones R.G., McDonnell E., Some mechanisms of salt tolerance in crop plants, Plant Soil 89 (1985) 15-40.

[45] Hampson C.R., Simpson G.M., Effect of temperature, salt and osmotic potential on early growth of wheat (Triticum aestivum), Can. J. Bot. 68 (1990) 524-528.

[46] Ashraf M., Salt tolerance of pigeon pea Cajanus cajan (L.) Millsp. at three growth stages, Ann. Appl. Biol. 124 (1994) 153-164.

[47] Santa-Maria G.E., Epstein H., Potassium/ sodium selectivity in wheat and the amphiploid cross wheat $\times$ Lophopyrum elongatum, Plant Sci. 160 (2001) 523-534. 


\section{El calcio induce una tolerancia a la sal en los porta-injertos de pistacheros.}

Resumen - Introducción. Los suelos salinos pueden ejercer efectos diferentes en la germinación de las semillas y en el crecimiento de jóvenes plantas. Material y métodos. Se incubaron las semillas de dos porta-injertos de pistacheros (cultivares Ghazvini y Badami-e-zarand de Pistacia vera) a $20^{\circ} \mathrm{C}$ en la oscuridad en una solución de $150 \mathrm{mM}$ de $\mathrm{NaCl}$ o en soluciones de $150 \mathrm{mM}$ de $\mathrm{NaCl}$ enriquecidas con $\left(50,100\right.$, y 150) $\mathrm{mM}_{\text {de }} \mathrm{CaSO}_{4}$. Se plantaron estas semillas en maceteros que contenían una mezcla de tierra de jardín, arena y compost ( $1 / 3 \mathrm{v} /$ v) con el fin estudiar el efecto del sulfato de calcio en las plantas cultivadas en condición de estrés salino. Los tratamientos aplicados por agua de riego consistieron en un tratamiento testigo (agua desionizada sola); un tratamiento de estrés salino $(150 \mathrm{mM}$ de $\mathrm{NaCl}$ ); tres tratamientos de estrés salino con $50 \mathrm{mM}$ de CaSO4, $100 \mathrm{mM}$ de CaSO4, y $150 \mathrm{mM}$ de CaSO4 añadidos respectivamente a la solución salina (150 mM de $\mathrm{NaCl}$. Resultados y discusión. Para todos los tratamientos, el porcentaje final de germinación y el porcentaje final de las semillas que dieron plántulas de más de $20 \mathrm{~mm}$ fueron más elevados para el porta-injertos Ghazvini que para el porta-injertos Badami-e-zarand. El porcentaje final de germinación así como el porcentaje final de las semillas con plántulas aumentaron sensiblemente junto con el aumento de la concentración en $\mathrm{CaSO}_{4}$, salvo con la concentración más elevada en $\mathrm{CaSO}_{4}$. Las plantas cultivadas con $150 \mathrm{mM}$ de NaCl elaboraron menos materia seca y tuvieron un contenido inferior en clorofila en relación con aquellas desarrolladas sin $\mathrm{NaCl}$. Únicamente las adiciones de $\mathrm{CaSO}_{4}$ en las concentraciones de $(50$ y 100) $\mathrm{mM}$ fueron las que permitieron paliar los efectos negativos de la salinidad en el contenido en materia seca y en clorofila de planta. La concentración de sodio ( $\mathrm{Na}$ ) en los tejidos vegetales aumentó a la vez tanto en las hojas como en las raíces de las plantas en el único tratamiento con $\mathrm{NaCl}$. El porta-injertos Ghazvini tuvo un contenido en Na muy inferior. La adición de $\mathrm{CaSO}_{4}$ a la solución salina disminuyó notablemente la concentración de $\mathrm{Na}$ en las hojas y raíces. El porta-injertos Ghazvini fue más tolerante a la salinidad que el porta-injertos Badami-e-zarand. La acumulación de $\mathrm{Na}$ en las hojas y raíces indica un mecanismo posible por el cual el cv. Ghazvini se enfrentaría a la salinidad en medio del arraigamiento, y/o podría indicar la existencia de un mecanismo de inhibición del transporte de Na hacia las hojas. Las concentraciones de Ca y de K fueron inferiores en las plantas cultivadas en presencia de $\mathrm{NaCl}$ con respecto a aquellas procedentes de las plantas testigo; y, para el cv. Ghazvini, los contenidos de estos dos elementos se aumentaron en las hojas y raíces para las plantas tratadas con sulfato de calcio; para el cv. Badami-ezarand, los contenidos aumentaron en las únicas raíces.

Iran República Islámica / Pistacia vera / germinación / crecimiento / estrés osmótico / agua salina / sulfato de calcio / tolerancia a la sal 